\title{
Six words: two about Lebanon, two about disability and two about us all
}

\begin{abstract}
This article reproduces partially one of the lectures I delivered at the Université SaintJoseph de Beyrouth in October 2017. The main focus is disability itself and the tact that no one is immune to it. Whatever the social circumstances, one must always try to assure the disabled person the right to live, as well as to live with others. Likewise, it should not be forgotten that the sociological categories of "us" and "them" can change position in the twinkling of an eye.
\end{abstract}

Keywords: lebanon, disability, human life, social integration, solidarity
Volume 2 Issue 2 - 2018

\author{
João Vicente Ganzarolli de Oliveira \\ Centre of Reference in Assistive Technology of the Tércio Pacitti \\ Institute of the Federal University of Rio de Janeiro, Brazil
}

\begin{abstract}
Correspondence: João Vicente Ganzarolli de Oliveira, Centre of Reference in Assistive Technology of the Tércio Pacitti Institute of the Federal University of Rio de Janeiro, Tel 3938 9600,Email jganzarolli@usa.com
\end{abstract}

Received: March 26, 2018 | Published: April 18, 2018

\section{Introduction}

Friends let us talk about disability and disabled people. First of all, however, some historical and geographical facts require reflection from us. We are in the Saint Joseph University of Beirut- in the eyes of many, the best university in Lebanon and in the whole Middle East. With its 4.036 square miles, Lebanon is a small country in terms of Physical Geography. Nonetheless, its historical importance is enormous; 3.000 years ago or more, Lebanon played a leading role in the cultural scene of the Fertile Crescent; its neighbours were Egypt and Mesopotamia, the first cradles of civilization in the world. The history of Lebanon is a history of inventions, of opening of unknown territories and, to a certain degree, of colours as well. Pioneers in the field of the transmission (and perhaps the creation) of the phonetic alphabet, the ancient Lebanese (called Phoenicians) were also protagonists in the process of colonization of the Mediterranean Sea - experimental laboratory of the oceanic navigations that have culminated with the discovery of America in 1492 and of Brazil in $1500 .{ }^{1}$ The great Iberian navigators were the heirs of the extraordinary nautical achievements of the Phoenicians of the first millennium B.C. The very word "Spain" is of Phoenician origin: $i$-chefannim ("coast of the rabbits"), used by the Phoenicians and Carthaginians (those Phoenicians of the West) to designate the Iberian Peninsula as a whole. The word "Lebanon" comes from the Phoenician root $l b n=$ "white", certainly due to the snowy peaks of its mountains, namely "Mount Lebanon". "Phoenicia", in turn, derives from the Greek adjective phoinix = "purple", a clear reference to the industry and commerce of the coloured tissues that made the Phoenicians famous all around the Mediterranean Basin during Antiquity. Homer attributes to them the invention of the purple colour. ${ }^{2}$ By metonymy, phoinikogenés was the person born in the land of phoinix, namely Phoinike $=$ Phoenicia $=$ Lebanon. ${ }^{3}$ Intermediate colour between blue and red, purple is "often associated with royalty, magic, mystery and piety". ${ }^{4}$ What matters here is rather its mediating nature between a "cold" and a "hot" colour. Purple is a "right balance between two extremes", a special feature that evokes the classic concept of virtue: "the habit that makes man good and therefore capable of carrying out his mission". ${ }^{5}$ Socially speaking, what other mission do we have than treating the others as we want to be treated by them? ${ }^{6}$ Far from being a mere terrestrial version of hell, as Jean-Paul Sartre wanted ("hell is other people"), the other can provide a direct contact with the difference in relation to the norm - and that concerns, obviously, the disabled person, protagonist of our meeting; disability is a kind of "otherness".

As for the white, the other colour related to the country of Lebanon, it is a colour that results, in terms of light, from the union of all other colours and represents "purity, innocence, goodness and faithfulness". ${ }^{8}$ So important for us is the white colour that the author of Moby-Dick - certainly one of the most important literary works of all time - devotes an entire chapter to it. ${ }^{9}$ And this puts us in a special position, namely that of a direct connection with disability, because the central character of Moby-Dick is a disabled man. First published in 1851, Moby-Dick describes obsessive quest of Captain Ahab for revenge on the white whale Moby-Dick, who, during a previous whale hunting trip, devoured his leg, leaving him with whalebone prosthesis. We cannot forget either that. The sea travel is a symbolic death for the narrator, who bears the name of Ishmael, the illegitimate son of Abraham, and who, like his namesake, went into exile in the desert of the oceans, a moving world where familiar references are erased. ${ }^{10}$ This exile (or death) is also to be understood as a literary image of the loneliness that often affects the disabled person, frequent victim of abandonment and general indifference. In terms of painting, white is no longer the result of mixing of all other colours (grey is what we will have, in such a procedure); in this case, white is to be considered an absence of colour. ${ }^{11}$ In most cases, disability is also an absence; deficiency, its synonymous, is a word which Latin root is very illustrative in this respect: deficere $>$ defectus $>$ deficiency. Being deficient is not having something(s) that he, she or it was supposed to have, since deficiency is a kind of insufficiency. This applies to people and living beings in general, as well as to concrete and abstract beings. A certain commercial process is called "deficient" when it does not lead to the desired result; all the same, we speak of a certain person who is intellectually deficient, because his intelligence is below average for a human being; there is a deficit - a defect, let us say in his ability to understand. Sometimes, however, the handicap (that is to say, the deficiency) is manifested by means of "what exceeds the ordinary measure or the right balance". ${ }^{12}$ The hump is normal in camels in the same way as it is abnormal in us; a camel without a hump would be a disabled camel because of a lack, whereas a man with a hump would be handicapped because of an excess. This is the case of the famous Hunchback of Notre-Dame de Paris, a fictional character created by Victor Hugo (1802-1885). 
The deformed Quasimodo is described as "hideous" and a "creation of the devil". He was born with a severe hunchback, and a giant wart that covers his left eye. He was born to a Gypsy tribe, but due to his monstrous appearance he was switched during infancy with a physically normal baby girl (the infant Esmeralda) After being discovered, Quasimodo is exorcised and taken to Paris, where he is found abandoned in Notre Dame (on the foundlings' bed, where orphans and unwanted children are left to public charity) on Quasimodo Sunday, the first Sunday after Easter, by Claude Frollo, the Archdeacon of Notre Dame, who adopts the baby, names him after the day the baby was found, and brings him up to be the bell-ringer of the Cathedral. Due to the loud ringing of the bells, Quasimodo also becomes deaf. Although he is hated for his deformity, it is revealed that he is fairly kind at heart. ${ }^{13}$ Given that disability has always been able to affect any living being, at any time, it must be admitted that it is as old as life itself, which means to say that disability has been active on earth for the last 3.5 billion years. ${ }^{14}$ Therefore, the Quasimodos have always existed among the Homines sapientes sapientes, the youngest and only surviving species of the genus Homo, in its turn the youngest of the family Hominidae, already a newcomer in the order of the primates.

\section{Two words about disability}

Obviously, because of my disability, I need assistance. But I have always tried to overcome the limitations of my condition and lead as full a life as possible. I have travelled the world, from the Antarctic to zero gravity. Stephen Hawking In general terms, a disability (aka "handicap") is any limitation of activity or restriction of participation in society suffered in its environment by a person because of a substantial, lasting and permanent alteration of one or more physical, sensory, mental, cognitive or physical functions - as well as of multiple disability or of disabling health condition. ${ }^{15}$ The entry handicap of the Dicitionnaire actuel de la langue française speaks about a "diminution" and an "insufficiency" in terms of physical (motor or sensory), mental and social capacity. Those are categories that often overlap; no wonder that one handicap can be the cause of another. ${ }^{16}$ Being disabled is not the same as being sick; often, a disease can be controlled or even cured. The disease is rather a situation; disability, on the other hand, is a long-term condition that requires concrete tools (e.g., assistive technology) and abstract measures (e.g., policies of social emancipation). This means that society in general must be willing to adapt and adjust to the demands of human life as deprived of certain physical, mental and social attributes. Disability is as old as humanity. In fact, disability is as old as life itself; primitive animals and plants were already subject to the phenomenon of disability. Actually, if we consider life as a challenge governed by the law of "the survival of the fittest", it becomes clear that even stones "compete against each other" during the geological cycle; simply put, all stones are made of this raw material called magma and have the same aim: reach the surface of the Earth, stay here for hundreds of millions of years (or even more), for then and only then return to the same magma where they belong, in the centre of the Earth. ${ }^{17}$ And, during this struggle for emancipation from its place of origin, there will always be stones that become "disabled", so to speak. As far as human society is concerned, it must be made clear that the social integration of the handicapped person is not the same thing as his social inclusion.

When we talk about social integration, it means that the disabled person is the one who has to adapt to society, normally thanks to socalled assistive technology. "Assist", in this context, means "help to integrate". In reality,
Assistive technology is an umbrella term that includes assistive, adaptive, and rehabilitative devices for people with disabilities and also includes the process used in selecting, locating, and using them. People who have disabilities often have difficulty in performing activities of daily living (ADLs) independently, or even with assistance. ADLs are self-care activities that include toileting, mobility (ambulation), eating, bathing, dressing and grooming. Assistive technology can ameliorate the effects of disabilities that limit the ability to perform ADLs. Assistive technology promotes greater independence by enabling people to perform tasks that they were formerly unable to accomplish, or had great difficulty in accomplishing, by providing enhancements to, or changing methods of interacting with, the technology needed to accomplish such tasks. ${ }^{18}$ The cane of the blind, the wheelchair of the paraplegic, the hearing aid of the deaf and the computer programs to help the autistic are examples of assistive technology. In my view, every time we find a disabled person making use of assistive technology for integrating into society as a whole, we should stop what we are doing and applaud, because we are standing before a winner. The great majority of the disabled people is where we cannot see them; hidden from external eyes, invisible to the rest of society, they do not leave their homes (or cells, for instance, in Indonesia $\left.{ }^{19}\right)$ and are not included in the statistics.

Disability was already a large scale phenomenon among our most distant ancestors, who lived about 7 million years old. Assistive technology, however, regardless of its degree of simplification (e.g, canes and primitive prostheses), could not have existed before the last 2.5 million years, the time of Homo habilis, the first to have hands properly said, i.e., "universal instruments" agile enough to modify nature, using stone, wood and bones as raw material for the manufacturing of tools. ${ }^{1}$ Assistive technology is, therefore, an invention of Homo habilis. Having lived in Africa between about 4.1 and 3 million years ago, the Australopithecus afarensis lacked the manual ability to produce and use tools; that means that assistive technology did not exist for him. ${ }^{20}$

In the social inclusion of disabled people, society must adapt to their particular condition, so that they feel due valued and important to the social body as a whole. Disabled people must be granted access to security, employment, housing and adequate transportation, health care, education, training and so on. ${ }^{21}$ In other words, a fully inclusive society is a fully accessible society vis-à-vis the social conquests mentioned above. For any society, there are conditions to be respected, in order to become inclusive; being the social inclusion a household name for accessibility to social conquests, it is necessary, first of all, that such conquests exist. One cannot think of an "inclusive education" when there is no education to give. Before thinking of pavements suitable for the locomotion of the blind, there must be pavements to walk on, and they must be well maintained. The invention of the wheelchair was preceded by the invention of the chair.

\section{Two words about us all}

We ourselves must walk the path.

\section{Buddha}

The fact is that nobody is "immune" to disability; safe those who are born and live in perfect conditions... but die young, since one or more kinds of disability (at least transportation problems) inevitably arise in old age. In any case, Disability continues to increase (...) as a major challenge which concerns us and our so called advanced society. The epidemiological and social data show that it does not decline, 
that it arouses renewed expectations and problems, and especially (...) that, in the end, it becomes a mere representation resulting from a compromise always fragile and likely to be challenged at any time..$^{22}$ It should not be forgotten that, in addition, "deadly diseases are now giving way to a growing number of chronic diseases, and advances in medicine are leading to an ever greater numbers of cures... and sequels also". ${ }^{23}$ Among those we have blindness, deafness, paralysis and so on. In other words, our longevity has increased, but it is a third age in which becoming handicapped is a possibility to be always taken into account. Careful consideration is also required of the rapidly growing number of work accidents, which is the price to be paid for the technological progress and the industrialization in general. Science fiction horror stories have already turned into tragic reality in many countries. Let us think about the Chernobyl disaster, whose number of victims are, still today, matter of scientific and political controversy. Genetically transmitted disabilities are just one of several effects of that nuclear accident that took place in occurred in Ukraine thirty two years ago. ${ }^{24}$ According to the philosopher, historian and anthropologist of infirmity Henri-Jacques Stiker, there will always be "the obligation to repair, and later compensate for, the damage done by the work accidents and this does not concern only the bosses (...), but also the entire national community. It is necessary to give back an economic and social place to injured workers". ${ }^{25}$ Whatever the social circumstances, one must always try to "assure the disabled person not only the right to live, but to live with others" ${ }^{26}$ Likewise, it should not be forgotten that the sociological categories of "us" and "them" can change position in the twinkling of an eye. ${ }^{27}$

\section{Acknowledgement}

Mr Thiago Antônio de Melo Oliveira and Mr Samir Funchal Oliveira, from the Brazilian Embassy in Beirut, invited me to come to Lebanon in order to give lectures on disability. I owe them, as well as Mrs Michele Kosremelli Asmar and Mrs Christiane Issa Bakhache, from the Université Saint-Joseph de Beyrouth, the splendid organization of all my lectures in Beirut. Mr Tony helped me with microphones, computers and some other modern devices which I do not know how to use properly, notwithstanding their undeniable utility. Ms Baleia Mink and Ms Linda Harb mediated the contacts. Father Philippe Yazbeck, Mr Antoine Haddad, Mrs Aline Rizek Haddad and Mrs Nayla Abi Antoun offered me their hospitality. Thank you all!

\section{Conflict of interest}

The author declare their is no any conflict of interest.

\section{References}

1. See Pline Historia naturalis, V, 12; and Giovanni Garbini et alii. Les Phéniciens, Paris, Stock, 1997:101-119 et passim.

2. See Iliad, IV, 161; VI, 219; Odyssey, XXIII, 201.

3. See Anatole Bailly. Dictionnaire grec-français, Paris, Hachette, 1990:2089.

4. https://en.wikipedia.org/wiki/Purple.
5. Aristotle. Nicomachaen Ethics, 1.106a 22 et passim.

6. See Lc 6,31; and Mt 7,12.

7. See Huis clos, Paris, Gallimard, 1944, scene V.

8. See Tina Sutton \& Bride Whelan. L'harmonie des couleurs. Le guide (traduction de Fabrice Radebac), Paris, Pyramyd, 2004:174.

9. See Herman Melville. Moby Dick or The Whale, London, Penguin Books, 2009:204-212; and Günter Blöcker. Lineas y perfiles de la literatura moderna (translated by Thilo Ullmann), Madrid, Guadarrama, 1969:31.

10. C Couffon et alii. Le nouveau dictionnaire des oeuvres de tous les temps et de tous les pays, Paris, Robert Laffont, 1994, IV: 4.720.

11. Tina Sutton \& Bride Whelan. L'hamonie des couleurs. Le guide, op. cit: 174 .

12. Jean-Marie Pruvost Beaurain et alii. Dicitionnaire actuel de la langue française, Paris, Flammarion, 1990: 434.

13. https://en.wikipedia.org/wiki/Quasimodo.

14. See Johannes Ebert et alii. Die grosse Chronik Weltgeschichte: vom Urknall zu den ersten Lebensformen: von 13.7 Mrd bis 292 Mio, Gütersloch/Munique, Wissen Media, 2008, v. I: 80 et passim.

15. Claude Hamonet. Les personnes en situation de handicap, Paris, PUF, 2012:97.

16. Jean-Marie Pruvost Beaurain et alii. Dicitionnaire actuel de la langue française, op. cit: 538 .

17. See https://fr.wikipedia.org/wiki/Cycle_g\%C3\%A9ologique.

18. https://en.wikipedia.org/wiki/Assistive_technology.

19. See https://www.hrw.org/report/2016/03/20/living-hell/abuses-againstpeople-psychosocial-disabilities-indonesia.

20. See Aristotle. De partibus animalium, 687 a et passim.

21. See https://fr.wikipedia.org/wiki/Australopithecus_afarensis

22. See http://www.thefreedictionary.com/social+inclusion.

23. Gilles Marchand. "Le handicap, enjeu de société", in https://www. scienceshumaines.com/le-handicap-enjeu-de-societe_fr_13809.html.

\section{Gilles Marchand. Ibidem.}

25. See http://www.businessinsider.com/birth-defects-related-to-chernobyl2016-4/\#more-than-5-of-strontium-90-was-released-during-thechernobyl-explosion-although-that-percentage-might-not-seem-veryhigh-strontium-90-is-the-most-dangerous-component-of-the-radioactivefallout-from-a-nuclear-explosion-1.

26. Quoted by Gilles Marchand. "Le handicap, enjeu de société", in https:// www.scienceshumaines.com/le-handicap-enjeu-de-societe_fr_13809. html.

27. Idem. 